\title{
Water Automation for Water Pump Controller using Android Application - Review
}

\author{
Mazharul Islam Nayeem \\ Stamford University Bangladesh \\ Dhaka, Bangladesh
}

\author{
Mahfida Amjad \\ Stamford University Bangladesh \\ Dhaka, Bangladesh
}

\begin{abstract}
Water is the important natural resources that should be used more efficiently. In manual system, users are supposed to visit their water tank to check the water level. The uncontrolled use of water leads to wastage of water and it causes water scarcity. Water automation is a process which is an automatic system to use water. The basic idea of water automation is to ensure the proper use of water and reduce the human effort. It is used for different purposes such as irrigation in the agricultural land, water pump controlling, water usage monitoring, billing of water usage etc. in different places like household, agricultural land, industry, hotel etc. Researchers have implemented several water automation projects using android application considering water pump controller, water level detection, water billing with detection and control of water leakage. This research presented a survey of water automation system for water pump controller using android application.
\end{abstract}

\section{General Terms}

Water automation, mobile application.

\section{Keywords}

Water pump controller, Water automation for water pump controller, android mobile application, water usage, water level.

\section{INTRODUCTION}

Water is an essential thing for life from the beginning of earth. Water automation is a process which is an automatic system to use water. The basic idea of water automation is to ensure the proper use of water and reduce the human effort. It is used for different purposes such as irrigation in the agricultural land, water pump controlling, water usage monitoring, billing of water usage etc. in different places like household, agricultural land, industry, hotel etc.

The process of controlling water tank uses the manual system yet. The huge amount of water is wasted every day for using manual process around the world. The continuous wastage of water for manual use is reducing the water level of the earth due to which a lot of lands are coming slowly in the zones of un-irrigated land [8]. In manual system of water tank the user needs to present at the water pump to turn it $\mathrm{ON}$ and OFF.

Researchers have implemented several water automation projects based on water pump controller, water level detection, water billing with detection and control of water leakage. An automated system uses Android Application to turn the water pump $\mathrm{ON}$ and $\mathrm{OFF}$.
This paper gives a survey of water automation for water pump controller using android application. The remainder of the paper is organized as follows. Section II is about the literature review. The system of water automation of water pump controller using android application is given in Section III. A comparative study has been discussed in Section IV. Finally, the paper concludes in Section V.

\section{LITERATURE REVIEW}

The literature review contains the brief discussion of some recent works of water automation for water pump controller system through android application. A model is presented in [1] which can collect water expense from a customer and detect the leakage in the water distribution system. The advantage of this model is that it can reduce the periodic tours of providers to each physical location to read each meter. Another advantage is that the bill of water usage can give based on the near real-time expense from the previous expense. Detecting leak supports to save water resources and energy and also reduce the cost.

The paper [2] proposes a water monitoring system by using an automatic overflow control circuit unit. The proposal is designed from the perspective of monitoring the flow of water into the tanks automatically and from the perspective of setting as per the user demands using a Mobile Application. The advantages of the system are the conservation of water resource, reduction of the manual attempt, and time to time changes over the situation of water storage with the help of sensors.

A basic model of the android application is proposed in [3] which states that water pumps can be switched ON and OFF with the assistance of radio transmitters and $\mathrm{Wi}-\mathrm{Fi}$ router. The wastage of water and the wastage of electricity can be avoided by this system. Users can check the water level of the tank and turn the pump ON and OFF from remotely using the android application.

Observing the water level with the help of the ultrasonic sensor is given in [4]. This system helps to conserve water and keep track of water usage and inform the users in situations of abuse of water. It assists the users to check the water level in the water tank. Moreover, users are capable to observe their water usage using the android application. Also, using the android application can avoid the wastage of water by cutting off the water supply.

A new architecture proposes for remote control of agricultural devices in [5]. This paper proposes the automation system with the latest electronic technology using microcontroller and bluetooth device. The project works automatically and hence reduces the human effort. This system provides the reminder to the user so that their irrigation activity can take place on time. From the advantage of android application, 
farmers are capable to manage the water pump and irrigation process remotely.

A model of variable rate microcontroller based automated irrigation system has been proposed in [6]. Solar power has used as the only source of power to control the entire process. Without visiting the agricultural land, farmers can find the information about the moisture level. Farmers can control the water pump based on the moisture level by sending a message from his/her cellular phone. Even when the farmers are away, the automated irrigation system always confirms the exact level of water in the agricultural lands.

Paper [7] discusses on automated systems based on the Android application which monitors the water pump and checks the water level in the agricultural land. Automated irrigation system leads farmers to apply the right amount of water at the right time and turn the water pump ON and OFF without using labor. It is capable to crop performance by ensuring adequate water when needed. It also helps to save time and reduce human errors by adjusting available soil moisture levels which increases their net profits.

\section{WATER AUTOMATION USING ANDROID APP}

This section describes the detail about water automation and android mobile application system.

\subsection{Water Automation}

Everyday water is being used in different places like house, agricultural land, industry, hotel etc. Water pumps are used to fulfill the water tank. The water pump is automatically turned $\mathrm{ON}$ and OFF using sensors and sent notification SMS to the user's cell phone. It can also be turned $\mathrm{ON}$ and $\mathrm{OFF}$ from anywhere by using android application.

The process of turning ON the water pump and turning it OFF is a manual process. Whether the water tank has not enough water, then someone has to turn ON the water pump to fulfill the water tank and someone has to turn OFF the water pump if the water tank is fulfilled or water is overflowing. A lot of water is wasted every day using this manual process. Nowadays, water automation system is widely used to reduce the human effort and the wastage of water.

Most of the users around the world use the manual process for water pump controller which costs them lots of money, human effort and time. The water level of water tank can be checked using android application. If water needs in water tanks, users can turn ON the water pump via an android application. Then they can turn OFF the water pump after reaching enough water in the tank.

\subsection{Android Mobile Application}

A mobile application is a program which is designed to run on a mobile device such as a phone, tablet, and watch. Mobile applications often stand in contradict to desktop applications that run on desktop computers, and with web applications that run on mobile web browsers in the mobile devices. One of the most popular mobile application development platform is the Android software development platform. Android software development is the process that creates new applications for devices based on the Android operating system. Applications are commonly developed in the Java programming language using the Android Software Development Kit. The Android software development kit (SDK) includes an extensive set of development tools [7].

Mobile applications are used for different purposes such as medical, blog, newspaper, games, security etc. Social networking companies also have their own applications. Different types of automation systems are controlled using mobile application. They are also being used in automatic water pump controller system for different purposes. In this section, the paper discusses the automatic water pump controller system using android application of recent works which have shown the interface of their mobile application. And these applications can be categorized for two purposes; one for irrigation and two for different places like hotel and household.

\subsubsection{Mobile Application for Irrigation}

Farmers use the manual irrigation system in their agricultural land. This manual irrigation system costs more human effort and wastes a lot of water. On the other hand, the automated irrigation system using an android mobile application reduces wastage of water and human effort. It also reduces the energy usage and saves money. It helps to irrigate at the right time using the right amount of water. As a result of using this system, farmers will produce more crops and they will can more profit.

Farmers can assure to check the last updated time feature of the Android mobile application that when they irrigated in their agricultural land last time. They can see the electricity status, motor status \& motor condition using this android mobile application. They can start, pause and stop the motor using this mobile application. This mobile application helps to set the timer for starting the motor to the certain time. It also helps to monitor for irrigation at the same time in many agricultural lands [7].

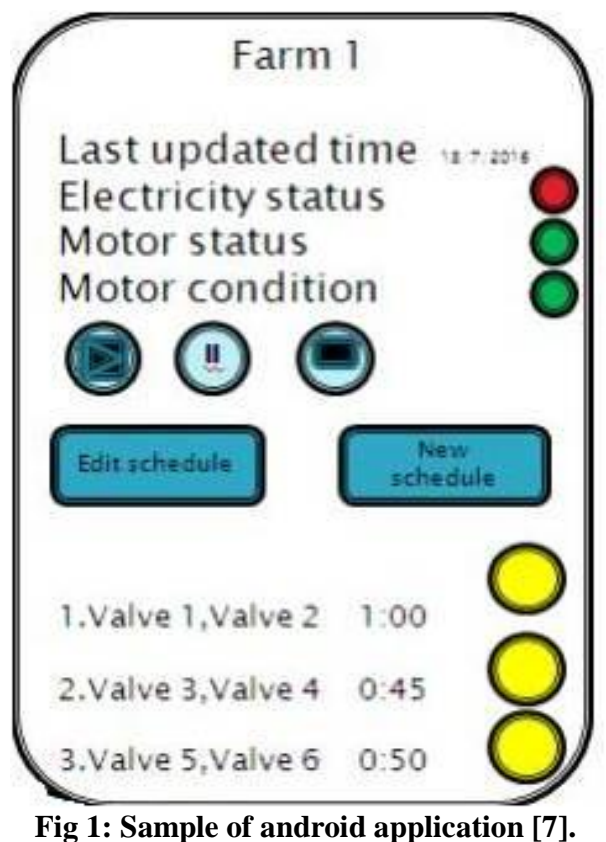

3.2.2 Mobile application for hotel and household The manual water pump controller system uses in different places like hotel and household. If the water level in the water tank is the last stage, then someone has to turn ON the water pump for this manual process. Again, someone has to turn OFF the water pump for this manual process when the water 
tank is fulfilled or water is overflowing. Thus, this manual water pump controller system wastes a lot of water every day around the world. Whereas the automated water pump controller system using an android mobile application reduces human effort and wastage of water. It also saves money and reduces the electricity usage.

Users can view the water level percentage in the water tank. It helps to check the water pump status like when the water pump turns ON and turns OFF It also helps to check when the water tank is fulfilled with the help of the time-left feature and when the water pump was turned $\mathrm{ON}$ with the help of timeelapsed feature of the mobile application. Users can also switch the water pump OFF tapping on the Stop Pump button or may choose to stop the water pump after a certain amount of time. They can customize the app interface and accessibility from the Settings. They can also get information about the app and tutorial from the Help menu. They can change the application interface theme from Settings option. The water pump can be set to turn OFF at a particular level of water in the tank [3].

In [4] it states that this system can reduce the water usage cost with the help of this automated system. The user of the system can also cut off the water supply if the water usage limit is crossed. Users can check the water usage on daily basis or monthly basis using the system. The system admin can view the water usage with the help of the mobile application in a house or apartment building. The house or apartment owners can cut-off the water supply when he/she is not at home and water tap is left open. The system admin also has special rights to cut off the water supply in an apartment building if the apartment owner is not able to do so.
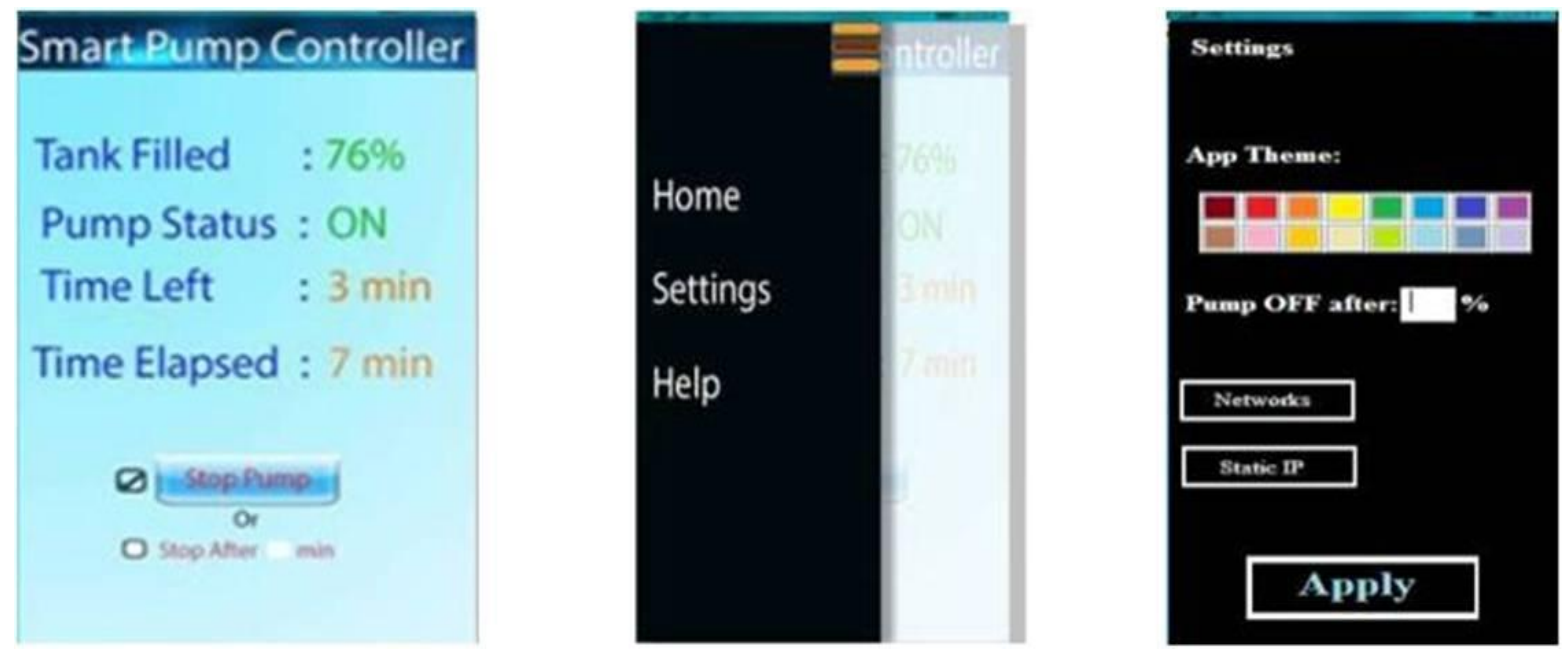

Fig 2: Home screen (left), menu (middle), settings (right) [3].
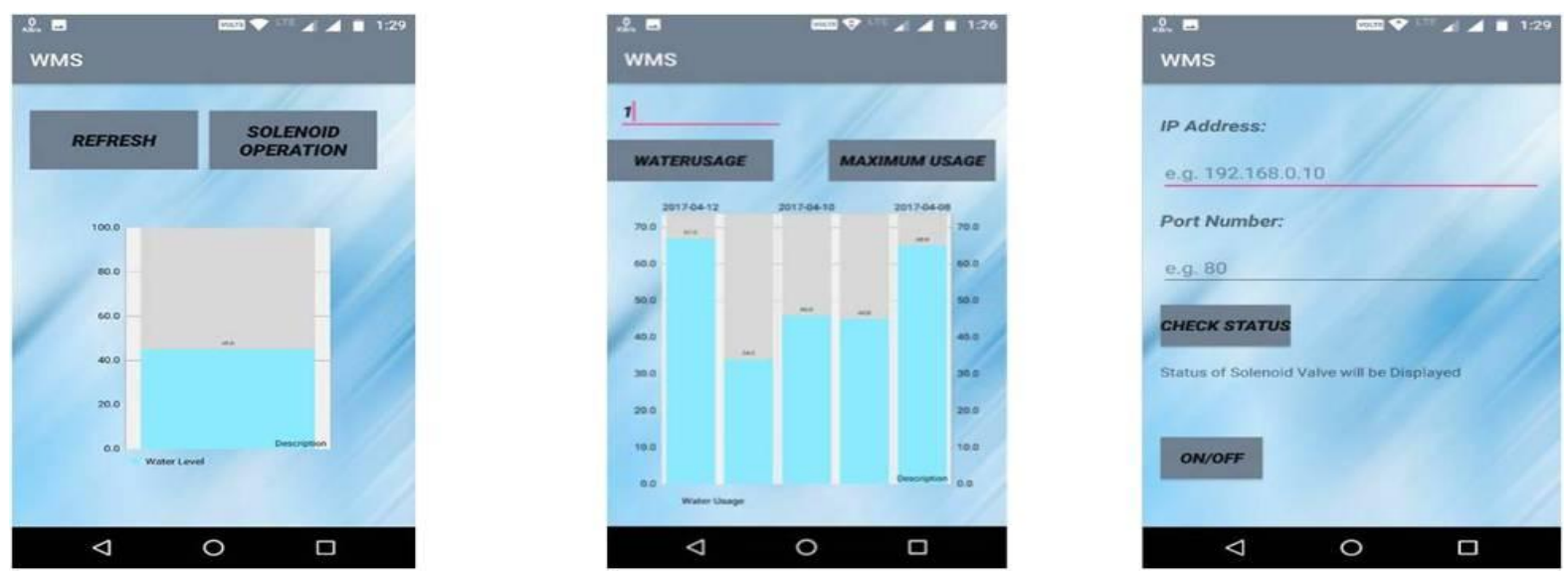

Fig. 3: Android application to view water level in the tank (left), to view water usage of a particular flat (middle), to control the solenoidal valve (right) [4]

\section{DISCUSSION}

The classification of water automation system for water pump controller and irrigation describes based on hardware, software, and technology. The irrigation system constructs using the mobile application based on Android operating system and also using only hardware. The water pump controller system constructs only using the mobile application based on Android operating system. The comparison of water automation system for irrigation using android application of existing works is discussed in Table 1. 
Table 1. Comparison among existing water automation systems using mobile application

\begin{tabular}{|c|c|c|c|c|}
\hline Research Works & Hardware & Technology & Features & Lacking \\
\hline $\begin{array}{l}\text { Automated Water } \\
\text { Billing with } \\
\text { Detection and } \\
\text { Control of Water } \\
\text { Leakage using } \\
\text { Flow } \\
\text { Conservation [1] }\end{array}$ & $\begin{array}{l}\text { GSM Module, } \\
\text { Transceiver, } \\
\text { Microcontroller }\end{array}$ & $\begin{array}{c}\text { Zigbee, } \\
\text { GSM }\end{array}$ & $\begin{array}{c}\checkmark \\
\checkmark \\
\text { through leakages } \\
\checkmark \quad \text { use of } \\
\text { Automatic Meter Reading system } \\
\text { has led to effective water auditing } \\
\checkmark \quad \text { no need of human power } \\
\text { because water billing is done } \\
\text { automatically by transceiver }\end{array}$ & $\begin{array}{c}\text { There is no } \\
\text { detail } \\
\text { discussion } \\
\text { about how the } \\
\text { mobile } \\
\text { application } \\
\text { interacts with } \\
\text { the system } \\
\end{array}$ \\
\hline $\begin{array}{c}\text { Automated Water } \\
\text { Tank Overflow } \\
\text { Control Unit } \\
\text { Integrated with } \\
\text { Mobile } \\
\text { Application [2] }\end{array}$ & $\begin{array}{c}\text { Arduino, } \\
\text { Bluetooth Device, } \\
\text { Water Pump, } \\
\text { Sensor }\end{array}$ & Bluetooth & $\begin{array}{l}\checkmark \\
\text { manual and automatic, people with } \\
\text { no smart phones would have to } \\
\text { choose the automatic only and for } \\
\text { the manual monitoring a display } \\
\text { board could be replaced in the place } \\
\text { of the mobile application }\end{array}$ & $\begin{array}{c}\text { There is no } \\
\text { detail } \\
\text { discussion } \\
\text { about how the } \\
\text { mobile } \\
\text { application } \\
\text { interacts with } \\
\text { the system }\end{array}$ \\
\hline $\begin{array}{c}\text { Android Based } \\
\text { Smart Water } \\
\text { Pump Controller } \\
\text { With Water Level } \\
\text { Detection } \\
\text { Technique [3] }\end{array}$ & $\begin{array}{l}\text { Sensor, } \\
\text { Transmitter, } \\
\text { Router }\end{array}$ & $\begin{array}{c}\text { Wi-Fi } \\
\text { Network }\end{array}$ & $\begin{array}{l}\checkmark \quad \text { it can be used to fill up } \\
\text { the water tank and in turn it can } \\
\text { prevent wastage of water }\end{array}$ & \\
\hline $\begin{array}{l}\text { Fully Automated } \\
\text { System for } \\
\text { Monitoring Water } \\
\text { Usage Using } \\
\text { SMS and Android } \\
\text { Application [4] }\end{array}$ & $\begin{array}{c}\text { Arduino, GSM } \\
\text { Module, } \\
\text { Ultrasonic } \\
\text { Sensor, Water } \\
\text { Flow Sensor, } \\
\text { Solenoid Valve }\end{array}$ & $\begin{array}{c}\text { Wi-Fi } \\
\text { Network }\end{array}$ & $\begin{array}{cc} & \text { it can Check Water Level } \\
\checkmark & \text { check Water Usage } \\
\checkmark & \text { cut-Off Water Supply }\end{array}$ & \\
\hline $\begin{array}{l}\text { Automation in } \\
\text { Farming Using } \\
\text { Android } \\
\text { Application [5] }\end{array}$ & $\begin{array}{l}\text { Arduino, } \\
\text { Bluetooth Device, } \\
\text { Sensor }\end{array}$ & $\begin{array}{c}\text { Wi-Fi } \\
\text { Network }\end{array}$ & $\begin{array}{cc}\checkmark & \text { it can remotely on/off } \\
\text { water pump using bluetooth. } \\
\checkmark & \text { It can emotely on/off } \\
\checkmark & \text { cultivation process. } \\
\checkmark & \text { It can remotely on/off } \\
\checkmark & \text { seeding process. } \\
\text { It can remind the farmer } \\
\text { about their scheduled activity. }\end{array}$ & $\begin{array}{c}\text { There is no } \\
\text { detail } \\
\text { discussion } \\
\text { about how the } \\
\text { android } \\
\text { application } \\
\text { interacts with } \\
\text { the system } \\
\end{array}$ \\
\hline $\begin{array}{l}\text { Automated } \\
\text { Irrigation System } \\
\text { using Solar } \\
\text { Power [6] }\end{array}$ & $\begin{array}{l}\text { Microcontroller, } \\
\text { Water Pump }\end{array}$ & $\begin{array}{c}\text { Solar power } \\
\text { system }\end{array}$ & $\begin{array}{l}\checkmark \quad \text { the model ensures the } \\
\text { sufficient level of water in the } \\
\text { paddy field avoiding the under- } \\
\text { irrigation and over-irrigation. } \\
\checkmark \quad \text { Farmers can remotely } \\
\text { ON/OFF the motor by using cell } \\
\text { phone even from away. } \\
\checkmark \quad \text { the system is secured with } \\
\text { password for the restricted number } \\
\checkmark \quad \text { of users. } \\
\text { sufficient amount of power to drive } \\
\text { the system. }\end{array}$ & $\begin{array}{c}\text { There is no } \\
\text { detail } \\
\text { discussion } \\
\text { about how the } \\
\text { mobile } \\
\text { interacts with } \\
\text { the system }\end{array}$ \\
\hline $\begin{array}{c}\text { Study of Arduino } \\
\text { for Irrigation } \\
\text { Based Control } \\
\text { Using Android } \\
\text { App [7] }\end{array}$ & $\begin{array}{l}\text { GSM Module, } \\
\text { Arduino, Sensor, } \\
\text { Water pump }\end{array}$ & $\begin{array}{l}\text { GSM, } \\
\text { UMTS, } \\
\text { Zigbee }\end{array}$ & $\begin{array}{ccc}\checkmark & & \text { it can check electricity } \\
& \checkmark & \text { motor status } \\
\checkmark & \text { motor condition }\end{array}$ & \\
\hline
\end{tabular}




\section{CONCLUSION}

Water is the important natural resources that should be used more efficiently. In earlier days, users are supposed to visit their water tank to check the water level manually. Moreover, the uncontrolled use of water leads to wastage of water and it causes to terminate ultimately water scarcity. To avoid more human efforts and errors water automation system can be used. Users can also turn the water pump ON and OFF using an Android Application. This is an efficient and economical way to reduce water wastage and human efforts. Hence, there is a lot of future scope and the researcher should give highest priority to improve the system.

\section{REFERENCES}

[1] M. M. Raykar, Parijata Vinod, Parinita Vinod, Preethi K. M, L. Jain, "Automated Water Billing with Detection and Control of Water Leakage using Flow Conservation," International Journal of Engineering Development and Research, vol. 3, issue 2, pp. 285-287, 2015.

[2] S. Gowri, P. Pranathi, K. Sravya, "Automated Water Tank Overflow Control Unit Integrated with Mobile Application," International Journal on Information Sciences and Computing, vol. 9, no. 2, pp. 10-12, 2015.

[3] S. Paul, M. Das, A. Sau, S. Patra, "Android Based Smart Water Pump Controller with Water Level Detection Technique," International Journal of Advanced Research in Computer and Communication Engineering, vol. 4, issue 12 , pp. 534-537, 2015
[4] A. Nikam, N. Warhade, R. Dhawale, S. Prabhu, G. Deshmukh, "Fully Automated System for Monitoring Water Usage using SMS and Android Application," International Research Journal of Engineering and Technology, vol. 4, issue 5, pp. 2548-2551, 2017.

[5] S. S. Patil, V. D. Nikam, "Automation in Farming using Android Application," in Proc. International Conference on Recent Innovations in Engineering and Management, 2016, pp. 572-576.

[6] Jia Uddin, S. M. Taslim Reza, Q. Newaz, Jamal Uddin, T. Islam, J. M. Kim, "Automated Irrigation System using Solar Power," in Proc. International Conference on Electrical and Computer Engineering, 2012, pp. 228-231.

[7] P. P. Karande, P. N. Sawardekar, P. B. Patil, Prof. Z. J. Tamboli, "Study of Arduino for Irrigation Based Control using Android App," International Journal of Advanced Research in Computer Engineering \& Technology, vol. 6, issue. 1, pp. 46-49, 2017.

[8] Muhamad Azman Miskam1, Othman Sidek, Inzarulfaisham Abd Rahim, Muhammad Qayum Omar, Mohammad Zulfikar Ishak, "MalaysiaFully Automatic Water Irrigation and Drainage System for Paddy Rice Cropping in Malaysia ," IEEE 3rd International Conference on System Engineering and Technology, 19 20 Aug. 2013, Shah Alam, Malaysia. 